\title{
等尺性運動負荷の血液凝固能および 血小板機能に及ぼす影響
}

一虚血性心疾患群と健常群との比較—

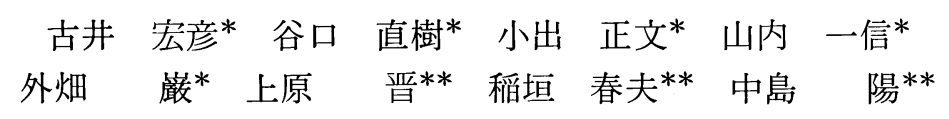

Effects of isometric exercise on blood coagulability and platelet function

Comparison between patients with ischemic heart

disease and healthy controls-

\begin{abstract}
Hirohiko HURUI*, Naoki TANIGUCHI*, Masahumi KOIDE*, Kazunobu YAMAUCHI*, Iwao SOTOBATA*, Susumu KAMIHARA**, Haruo INAGAKI** and Akira NAKAJIMA**
\end{abstract}

Key words: handgrip isometric exercise, ischemic heart disease, blood coagulability, platelet function

The effects of sustained handgrip isometric exercise on blood coagulability and platelet function were studied in 10 patients with ischemic heart disease (IHD) and 10 healthy controls. Isometric exercise was performed for $3 \mathrm{~min}$ at the $50 \%$ level of maximal voluntary contraction. Blood sampling was made at rest, and immediately and $6 \mathrm{~min}$ after exercise.

No significant changes in the platelet sensitivity to ADP-aggregation and $\beta$ TG levels were noticed in IHD and control groups after exercise. In IHD fibrinogen levels were higher and antithrombin III activities were lower than those in healthy controls at rest. These two substances increased after exercise in both groups. Prothrombin time and partial thromboplastin time were shortened immediately after exercise in IHD, while these measurements showed no significant changes in healthy controls, The activity of factor VIII increased

* 名古屋大学医学部第一内科 [个466 名古屋市昭和区鶴舞町], The First Department of Internal Medicine, Nagoya University School of Medicine, Nagoya, Japan.

** トヨタ病院循環器内科, Department of Cardiovascular Medicine, Toyota Hospital, Toyota, Japan. 
immediately after exercise in IHD and the activity of factor XII in healthy controls, respectively.

In conclusion, platelet function was not altered in both groups after exercise. However, there was a tendency to an increase in blood coagulability after exercise in IHD. Hemostatic unbalance might be induced after the isometric exercise in IHD patients.

\section{目的}

等尺性運動負荷試験を虚血性心疾患患者和よ び健常者に施行し, 等尺性運動負荷の血液凝固 能抽よび血小板機能に及ぼす影響について両群 で比較検討した。

\section{I. 対象および方法}

平均年㱓54.9歳の虚血性心疾患 (IHD) 患者 男子10名 (陳旧性心筋梗塞症 7 名, 労作性狭心 症 3 名）打よび平均年齢 38.0 歳の健常男子 10 名 に Handgrip 法等尺性運動負荷試験を施行し, 最大握力の $50 \%$ で 3 分間の負荷を与えた. 安 静時, 負荷終了直後抢よび 6 分後に採血し, 血 液凝固能および血小板機能に関与する各諸量を 以下の方法に従い測定した. PT, PTT, ATIII 活性および VIII ・ IX ・ XI ・ XII 凝固 因子活性 は光学的比濁法により, Fbg. 量は一元免疫拡 散法により測定した。血漿 cAMP 抢よび血漿 $\beta$-TG はRIA により, 全血抢よび多血小板血 漿中の血小板数は Coulter 法により求めた. 血
小板凝集曲線は凝集惹起物質として ADP を用 い吸光度法により求め, 2 次凝集を惹起する最 低有効濃度を $2^{n} \mu \mathrm{M}$ で表わし，一n を凝集感受 性とした。

\section{II. 成 績}

負荷により血小板凝集感受性および $\beta$-TG 值 は両群とも有意な変化を示さなかった. 健常者 の cAMP 量は負荷終了直後増加し（安静時 $16.2 \pm 4.3 \mathrm{pMOL} / \mathrm{m} l$ vs 負荷終了直後 $18.7 \pm$ $3.0 \mathrm{pMOL} / \mathrm{m} l, \mathrm{p}<0.01), \mathrm{PRP}$ 中の血小板数 は IHD 患者で負荷終了直後増加した. 安静時 IHD 患者の Fbg. 量は健常者に比して高く, ATIII 活性は低かった。両群とも負荷後 Fbg. 量は増加し (IHD 群: 安静時 $385 \pm 62.4 \mathrm{mg}$ / $\mathrm{d} l$ vs 負荷終了直後 $399 \pm 57.7 \mathrm{mg} / \mathrm{d} l, \mathrm{p}<0$. 01 ; 健常群: 安静時 $301 \pm 56.2 \mathrm{mg} / \mathrm{d} l$ vs 負荷 終了直後 $310 \pm 54.5 \mathrm{mg} / \mathrm{d} l, \mathrm{p}<0.01)$, ATIII 活性も増加した（IHD 群：安静時 $103 \pm 8.7 \%$ vs 負荷終了直後 $110 \pm 9.2 \%, \mathrm{p}<0.01$; 健常 群 : 安静時 $118 \pm 17.2 \%$ vs 負荷終了直後 131

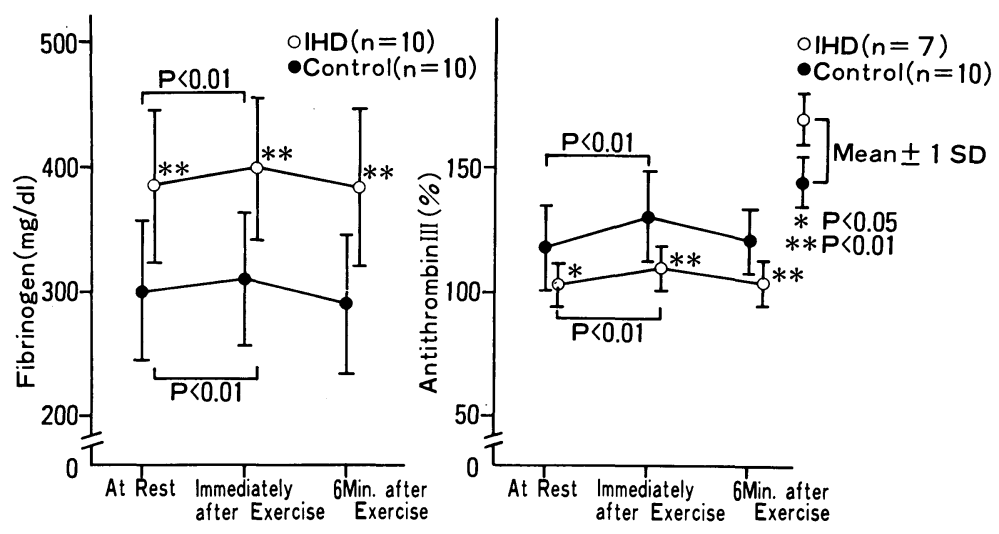

Fig. 1 Changes in fibrinogen levels and antithrombin III activities by handgrip isometric exercise in patients with IHD and healthy controls 


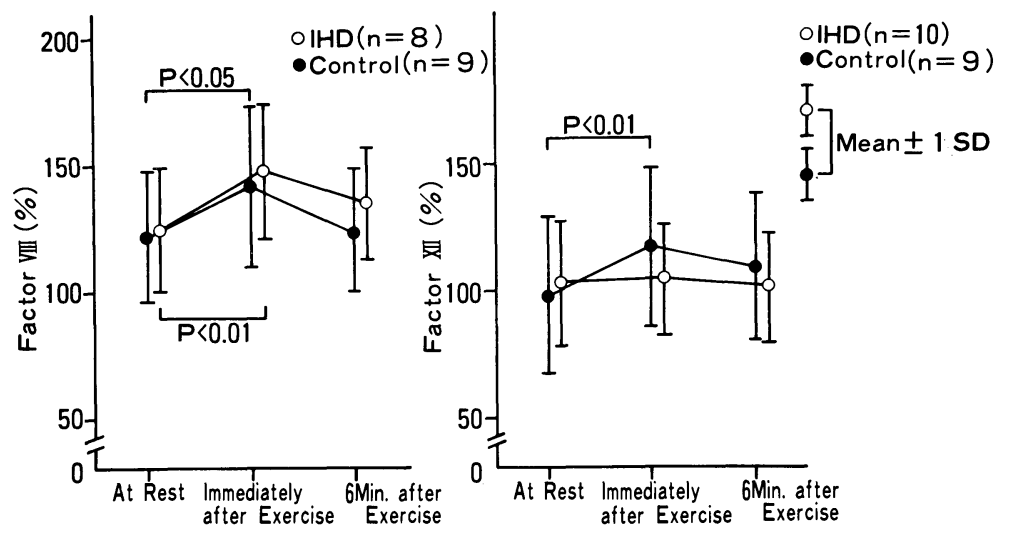

Fig. 2 Changes in factors VIII and XII activities by handgrip isometric exercise in patients with IHD and healthy controls

$\pm 18.1 \%, \mathrm{p}<0.01$ ) (図 1). IHD 患者の PT および PTT は負荷により短縮した。 IHD 患 者の VIII 凝固因子活性は負荷により増加し （安静時 $125 \pm 24.5 \%$ vs 負荷終了直後 $148 \pm$ $26.6 \%, \mathrm{p}<0.01)$ ，XII 凝固因子活性は健常者 に打いてのみ増加した（図 2). IX・XI 凝固因 子活性には両群ともに有意な変化はみられなか った.

\section{III. 考案および結論}

佐野らは，Handgrip 等尺性負荷後の血小板 凝集感受性拉よび $\beta$-TG 值は IHD 患者で増加 し，健常者では変化しなかったと報告した ${ }^{1,2)}$. 本研究では健常群および IHD 群に括いても, 血小板凝集感受性, $\beta-T G$ 值には有意な変化が みられなかった。 この差異は対象括よび方法論 的差異に基づくかもしれないが，等尺性負荷の 血小板機能への影響は少ないように思われる. 血液凝固系因子については安静時および負荷後 ともに $1 \mathrm{HD}$ 群の Fbg. 量は高く, ATIII 活性 は低かったＰT 拈よび PTT は IHD 群にお。
いて負荷により短縮し，VIII 凝固因子活性は両 群に括いて増加したが, IHD 群の変化が大で あった。これらの成績は IHD 群で安静時, 負 荷後ともに血液凝固系が充進していることを示 す. IHD 群と健常群との年齢的差異を考慮に 入れなければならないが，IHD 群では健常群 に比して等尺性運動時に血液凝固系の不均衡が 生じる可能性の強いことが示唆された.

\section{文 献}

1) Sano, T., Motomiya, T., Yamazaki, H. and Shimamoto, T.: Enhancement of platelet sensitivity to ADP-aggregation by isometric exercise in arteriosclerotic patients and its prevention. Thromb sis and Haemostasis, 37; 329 338, 1977.

2) Sano, T., Motomiya, T. and Yamazaki, H.: Platelet release reaction in vivo in patients with ischemic heart disease after isometric exercise and its prevention with Dipyridamole. Thrombosis and Haemostasis, 42; 1589 1597, 1979. 